Ulu, H. (2018). Ekran okuma öz yeterlik ölçeği: Geçerlik ve güvenirlik çalışması. Ana Dili Eğitimi Dergisi, 6(1), 148165.

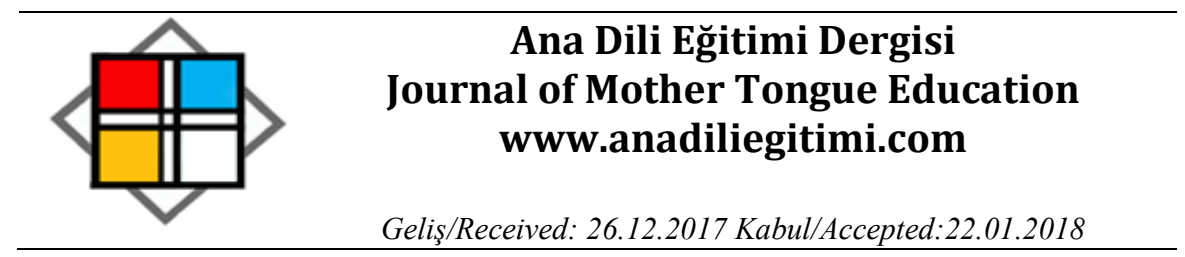

\title{
Ekran Okuma Öz Yeterlik Algı Ölçeği: Geçerlik ve Güvenirlik Çalışması*
}

\author{
Hacer $U L U^{* *}$
}

Öz

Bu çalışmanın amacı öğretmen adaylarının ekran okuma öz yeterlik algılarına yönelik bir ölçme aracı geliştirmektir. Çalışmada ilgili literatür taranmış ve uzman görüşleri göz önünde bulundurularak 40 maddelik bir madde havuzu oluşturulmuştur. Uzman görüşleri alındıktan sonra ortaya çıkan 28 maddelik form bir devlet üniversitesinin eğitim fakültesine kayıtlı 228 öğrenci üzerinde uygulanmıştır. Açımlayıcı faktör analizi sonucunda, 16 madde ve 4 alt boyuttan oluşan form, toplam varyansın \%53.07'sini açıklamaktadır. Yapılan DFA sonucunda da uyum indeks değerlerine bakılmış ve 16 maddeden oluşan ölçeğin 4 faktörlü yapısının bir model olarak doğrulandığı görülmüştür. Ölçeğin güvenirliğini belirlemek için test edilen Cronbach-Alfa iç tutarlık ve test-tekrar test güvenirlik katsayı değerlerine göre ölçeğin güvenilir olduğu sonucuna varıımıştır. Anahtar Kelimeler: Ekran okuma, öz yeterlik algısı, ölçek geliştirme, geçerlik ve güvenirlik

\begin{abstract}
Screen Reading Self-Efficacy Perception Scale: A Study of Validity and Reliability Abstract

The aim of this study is to develop a scale to assess pre-service classroom teachers' screen reading self-efficacy perceptions. In the study, based on relevant literature survey, an initial draft of the scale which contained 40 items was formed. Having obtained expert opinions on the initial draft, 28 items which were decided to be included in the scale was administered to 228 students in the education faculty of a state university. As a result of exploratory factor analysis, a four-factor 16item scale which accounted for $53.07 \%$ of the total variance emerged. In the confirmatory factor analysis that followed, consistency index values were identified and the four-factor scale with 16 items was confirmed. The Cronbach-Alpha internal consistency values and test-retest reliability coefficients that were calculated in order to determine the reliability of the scale showed that the scale was reliable.
\end{abstract}

Key Words: Screen reading, self-efficacy perception, scale development, validity, reliability

\section{Giriş}

21. yy. da teknoloji ve multimedya araçlarının eğitim ortamlarıyla bütünleştirilmesinin giderek önemi artmaktadır. Bu durum internet, e-posta, çevrimiçi öğrenme çevreleri gibi bilgi ve iletişim teknolojilerinin eğitimciler ve öğreniciler için popülerliğini artırmıştır. "Görsel ve işitsel unsurları bünyesinde barındıran içerik öğrenicilerin ilgisini çekmektedir" (Jung, 2011; Akt. Hsieh ve Dwyer, 2009, s.36). Bu doğrultuda Chou (2011) okuyucuların günümüzde geleneksel basılı metinlere ilişkin okuma alışkanlıklarını aşmaları ve elektronik metinlerin doğasını içeren yenilikçi yaklaşım ve statejileri

\footnotetext{
* Bu çalışmanın pilot uygulaması 19-21 Ekim tarihlerinde düzenlenen EYFOR-8 Uluslararası Eğitim Yönetimi Forumu'nda sözlü bildiri olarak sunulmuş olup 2017-2018 eğitim-öğretim yılı güz döneminde veri analizi için tekrar uygulama yapılmıştır.

** Öğr. Dr. Afyonkarahisar Milli Eğitim Müdürlüğü Bozhüyük illkokulu, hacerulu03@gmail.com
} 
edinmeleri gerektiğini ifade etmektedir. Basılı metinlerden farklı olarak ekran okuma kullanıcıların başıı, paragraf, bağlantı, düğme vb. HTML etiketlerinde gezinerek okumalarına imkân tanır (JAWS, 2011). Ekran okuma anlama, sağlık, kullanışlılık, sayfayı biçimlendirme gibi faktörler açısından basılı materyallerden okumaya göre bazı farklılıklar göstermektedir.

Coiro (2003: 459)'ya göre "yeni okuryazarlık uygulamaları okuduğunu anlama becerisinin gelişiminde yeni yol ve metin formatları oluşturmuştur. Okur basılı materyallerden ziyade çok katmanlı metin ya da hipermetin gibi elektronik dokümanlarla etkileşim içerisindedir". Russo ve Watkins (2008: 226)'e göre "yeni okuryazarlık, kültürel açıdan bilgi tüketimi ve üretimi yapmak için dijital teknolojilerin kullanımını içeren gerekli becerilerdir". Bu süreçte okumanın özgül amacı ne olursa olsun, insanlar genellikle okumak zorunda oldukları büyük miktarda bilgi ile karşı karşıya kalırlar. Bilişsel aşırı yük çevrimiçi sayfalarda büyük miktarda bilgi edinirken ortaya çıkan temel bir sorundur (Ahmed ve ark., 2012; Sweller, 1988). Bu durum okurun okudukları arasında ilişki kurmasını olumsuz etkilemesinin yanında Woddy, Daniel ve Baker (2010)'a göre sayfaları yönetmeyi, gezinmeyi ve istenilen bölümlere atlamayı zorlaştırmaktadır. Muter ve Maurutto (1991)'ya göre okurun ekrandan okurken kolayca ve hızlıca göz atabilmesi metin içi ayrıntıları hatırlama yeteneklerinin gelişimini olumsuz etkilemektedir. Güneş (2010) ise farklı bir açıdan bakarak sayfaların bütün olarak görülmemesinin metindeki ana ve alt başlıkları rahatça izlemeyi engellediğini ve böylece ağ kurma, karşılaştırma yapma ve anlam zinciri oluşturma sürecinin güçleştiğini ifade etmektedir. Rose (2011) ise bu ifadeye benzer şekilde okuma uygulamalarının giderek parçalı hale geldiğini belirtmiştir. O'Hara ve Sellen (1997)'a göre ekran okumaya göre basılı materyallerden okurken not almanın kolaylı̆̆ı gibi sunduğu fırsatlar belirgin farklılıkların oluşmasına yol açmaktadır. Duran ve Alevli (2014b)'ye göre ekranda dikkat dağıtıcı ögelerin olması metne odaklanmayı zorlaştırabilmektedir. Ekranda farklı programlara, internete yönelip asıl metinden uzaklaştırmaktadır. Dolayısıyla ekran okuma basılı metinlere göre daha gelişmiş anlam oluşturma süreci ortaya çıkarmaktadır.

Ekran okuma sürecinde görsellerle, animasyonlarla ve bazen sesle desteklenen içerikler daha iyi öğrenilip kolayca hatırlanmasına (Duran ve Alevli, 2014b, s.120) karşın okuma süreci giderek parçalı hale gelmeye başlamıştır (Carusi, 2006; Rose, 2011). Bu durum göz hareketlerini olumsuz etkilemektedir. Göz yorgunluğu baskı tercihi için dikkate alınan etkenlerden birisidir. Örneğin Mercieca (2004)'nın çalışmasına katılanlar, bir süre sonra ekran okumanın göz yorgunluğuna sebep olduğunu ifade etmiştir. Böylece basılı metinleri okuyan öğrencilerin ekran tabanlı metinleri kullanan öğrencilere göre bir oturum süresinde okumaya devam etme olasılığının daha yüksek olduğu sonucuna ulaşılmıştır. Ekranın göz sağlığını olumsuz etkileyen etkenlerden diğeri de parlaklıktır. Duran ve Alevli (2014b: 115)'ye göre "ekran parlaklığı gözü çabuk yormasının yanında baş ağrısı yapabilmektedir". Özellikle uzun metinleri okumak ekranda zorlaşmaktadır. Ulu (2017) tarafından yapılan araştırmada öğretmen 


\section{Ekran Okuma Öz Yeterlik Ölı̧eği: Geçerlik ve Güvenirlik Çalışması}

adayları e-kitaba yönelik ekranın göz sağlığını tehdit etmesine ilişkin tablet ve bilgisayar metaforlarını üretmişlerdir. Bu açıdan ekran okuma göz sağlığını olumsuz etkilemektedir.

Ekran okuma kullanışlılık açısından fırsatlar sunmaktadır. Spencer (2006: 33)'a göre bilgisayar teknolojisi ve yazılımlarının gelişimi notları, makaleleri ve kitapları basılı materyallerden ekrana transferini sağlamıştır. Bu metinler donuk değildir ve gezinmek için kolay erişim sağlar. Bu fırsat öğrenicilere sonsuz seçim ve esneklik verir. O'Hara ve Sellen (1997: 199) tarafından yapılan araştırmada katılımcılar kâğıt metninin destek ek açıklama içerdiğini, çevrimiçi metinlerin ise daha esnek olduklarını iddia etmiştir. Okuyucuların metinleri derinlemesine anlamaları, yapıları hakkında bilgi edinmeleri, yazma planları yapmaları, diğer belgelere çapraz başvurmaları ile okuma ve yazmayı bütünleştirmeleri gibi fırsatlar sunmaktadır. Linkler sayesinde dijital ortamdaki diğer metinlerle bağlantı kurularak metinler arası anlam kurulmaktadır. "Öğrenciler ekrandan okuma cihazlarının hafifliği ve taşınabilirliğinin yanında navigasyon, kullanım kolaylı̆̆ı, depolama kapasitesi gibi özelliklerini sevmektedir" (Gibson ve Gibb, 2011; Akt. Duran ve Alevli, 2014b, s.111). Bunun yanı sıra "metni istenilen boyutta değiştirebilme, bilgiyi düzenleme kolaylığı, kâğıt kullanımını azaltma, kâğıt masrafından kaçınma ve çevresel yararlar ekran okumayı tercih sebeplerinden birisi yapmaktadır" (Dyson ve Haselgrove, 2001; Akt. Duran ve Alevli, 2014b, s.111). Ulu (2017) tarafından yapılan araştırmada öğretmen adayları e-kitap kavramına iliş̧in materyalleri depolama kapasitesi kategorisinde kütüphane, kitap, dijital kütüphane gibi metaforlar, bilgiye kolay ulaşma kategorisinde telefon, jet, araba, modern araç gibi metaforlar, taşınabilirlik kategorisinde cüzdan, çanta, ayaklı gazete gibi metaforlar üretmişlerdir. Günümüzde ekran okumanın okuyuculara sağladığı fırsatlar bu okuma türünü basılı metinlere göre cazip hale getirmiştir.

Ekrandan okumanın diğer sunduğu fırsatlardan birisi de sayfayı biçimlendirme açısından esneklik sağlamasıdır. Çünkü ekrandan okurken sayfalar kişiselleştirilebilir, istenilen bilgilere daha hızlı ve kolay ulaşılabilir (Duran ve Alevli, 2014b). Ahmed ve ark. (2012)' na göre göz gezdirme okurun sayfalar hakkında genel izlenim elde etmesine ve neye ihtiyaç duyduğunu bulmasına yardımcı olur. Ekran tabanlı metinlerin diğer önemli avantajı daha kolay okunan büyük font boyutlarını kullanma seçeneklerini içermesidir (Burk, 2001). Bu avantajlarının yanında okurun tüm metni okumaması gibi olumsuz yönleri bulunmaktadır. "Ekran okumada okuyucu satırları düzenli olarak izlememekte, atlamalar yapmakta, resimlere bakarak ihtiyacı olan bilgileri aramaktadır. Bu tür okumada metin üzerinde göz gezdirilmekte, metindeki bilgilerin yeri aranmakta, metnin çeşitli bölümlerinden bilgiler toplanmaktadır. Yani metin satır satır okunmamaktadır. Böylece okuyucular derinlemesine okuma yerine metin üzerinde göz gezdirmektedir" (Güneş, 2009, s. 322).

Ekran okumayla ilgili yapılan çalışmalar uluslararası literatürde 20. yy. sonlarından itibaren yoğun biçimde çalışılmaya başlanmasına rağmen ulusal literatürde son yıllarda çalışılmaya 
başlanmıştır. Dil becerileri açısından incelendiğinde ekran okumanın okuduğunu anlama ve okuma tutumuna etkisi ile cinsiyet değişkenine göre değerlendirildiği görülmektedir. Okuma becerilerinin okuma ortamı (kâğıt-ekran) açısından karşılaştırılması sonucunda kâğıttan okuma lehine farklılık çıktığı (Baştuğ ve Keskin, 2012; Ercan ve Ateş, 2015; Ertem ve Özen, 2014; Kuru, Kaşkaya ve Calp, 2017), okuma ortamı açısından karşılaştırıldığında okuduğunu anlama ve okuma hızı açısından anlamlı farklııı çıktığı fakat kâğıttan okumaya yönelik daha olumlu tutum sergilendiği (Başaran, 2014), öğretmen adaylarının ekrandan okumaya göre basılı metinlerden okumayı tercih ettiği (Dağtaş, 2013) tespit edilmiştir. Sözü edilen araştırmalarda okuma becerisi açısından değerlendirildiğinde basılı materyaller lehine bulgular ortaya konmuştur fakat ulaşılan bulgularla tutarlılık göstermeyen araştırmalarda literatürde mevcuttur. Örneğin İleri-Aydemir, Öztürk ve Horzum (2013) ile Duran ve Alevli (2014) tarafından yapılan araştırmada bilgilendirici metinleri ekrandan okuyan öğrencilerin okuduğunu anlama düzeyleri basılı materyalden okuyan öğrencilerinkinden anlamlı derecede yüksek bulunduğu, Yaman ve Dağtaş (2013) tarafından yapılan araştırmada basılı metinlerle karşılaştıııldığında ekran okumanın okumaya yönelik tutuma önemli etkisinin olduğu tespit edilmiştir. Bu araştırmaların yanı sıra yapılan diğer araştırmalarda ekran okumanın özellikle cinsiyet değişkeni açısından incelendiği araştırmalarda mevcuttur. Gömleksiz, Kan ve Fidan (2013) tarafından yapılan araştırma hem erkek hem de kadın öğretmen adaylarının ekran okuma becerisi anlama alt boyutunda yüksek düzeyde öz yeterliğe sahip olduklarını ortaya koymuştur. Ancak ekran okumada erkek öğretmen adayları kadın öğretmen adaylarından daha fazla yarar sağladıklarını ifade etmiştir. Ekran okuma becerisi düzeyinde kız öğrenciler lehine anlamlı farklılık çıkması (Macit ve Demir, 2016a), ekran okumaya yönelik tutum açısından erkek öğrenciler lehine anlamlı farklılık çıkması (Maden ve Maden, 2016), ekran okuma tercih düzeyinde cinsiyete göre anlamlı farklılık oluşmaması (Macit ve Demir, 2016b) ekrandan ya da kâğıttan okuduğunu anlama düzeyinin cinsiyete göre anlamlı farklılık göstermediği (Ercan ve Ateş, 2015) tespit edilmiştir. Bu bağlamda ekran okuma çalışmaları değerlendirildiğinde ekran okumanın okuduğunu anlamaya, okuma tutumuna etkisinin belirlendiği ve cinsiyet değişkenine incelendiği araştırmalar üzerinde çalışıldığı görülmektedir. Ekran okuma bireylerin dil becerilerindeki başarılarına etki edebilir ya da etmeyebilir, bireyler bu okuma türüne karşı olumlu ya da olumsuz tutuma da sahip olabilirler. Peki, bireylerin ekran okumaya yönelik öz yeterlikleri ne düzeydedir? Öz yeterlik kavramının ortaya konması ve tanımlanmasına öncülük eden Bandura $(1986,1997)$ öz yeterlik inancını, "bireyin verilen bir göreve ilişkin eylemleri yapabileceğine, uygun davranış biçimini seçebileceğine ve harekete geçebileceğine ve gerekli çabada bulunabileceğine ilişkin inancı" olarak tanımlamaktadır (Akt. Ekinci, 2015, s.175). Aypay (2010)'a göre kişiler ne kadar güçlü yeterlik beklentilerine sahiplerse o kadar çok çaba harcayacaklardır. Yıldırım ve Illhan (2010: 302) ise bu konuda "bir eylemin planlanması, gerekli becerilerin farkında olunması ve örgütlenmesi, zorluklarla birlikte elde edilecek kazançların gözden geçirilmesi sonucunda oluşan güdülenme düzeyi gibi ögeleri içerir. Güçlü bir öz yeterlik başarı ve iyilik 


\section{Ekran Okuma Öz Yeterlik Ölçeği: Geçerlik ve Güvenirlik Çalışması}

halinin oluşmasını ve en önemlisi kişisel gelişimi ve becerilerin çeşitlenmesini sağlar". Sanal dünyanın bir parçası olmasının yanında gerçek hayatın bir parçası olan teknoloji konusunda alınan eğitim hayatın her safhası için merkezi bir rol oynamaktadır. Bu inanılmaz dönüşüm, eğitimcileri kendi temel ilkelerini yeniden düşünmeye, yaratıcı ve üretici yollar içinde bu yeni teknolojileri yeniden planlamaya yönlendirmektedir (Kellner, 2000). Kurudayıoğlu ve Tüzel (2010) yalnızca yazılı ve basılı metinler ile sınırlı kalan eğitimin teknolojinin etkisinde kalan bireylerin yaşantılarından uzak kaldığını ifade etmektedir. Teknolojiyle yoğun etkileşim içerisinde bulunduğumuz düşünülürse ekran okuma konusunda bireylerin öz yeterliklerinin yüksek olması bu okuma türüne karşı tutumlarına ve bu okuma türüne bağlı etkinliklerde akademik başarılarına olumlu yönde etki edecektir. Bu açıdan günümüzde ekran okuma öz yeterliğinin bireylere kazandırılması önemli konulardan birisi hale gelmiştir. Bu çalışmada öğretmen adaylarının ekran okumaya yönelik öz yeterlik algılarının tespit edilebilmesini hedefleyen bir ölçek geliştirilmiştir.

\section{Yöntem}

\section{Araştırma Modeli}

Bu araştırmada öğretmen adaylarına yönelik Ekran Okuma Öz Yeterlik Algı Ölçeği'ni (Bkz: EK 1) geliştirmek amaçlandığı için araştırma tarama modeline göre desenlenmiştir. "Tarama türü araştırmalar büyük gruplar üzerinde çalışma olanağı sağlar ve sosyal bilimlerde yaygın olarak kullanılır. Bu araştırma modelinde var olan durum gözlenir" (Karasar, 2005, s.77).

\section{Çalışma Grubu}

Çalışma grubunu bir devlet üniversitesinin eğitim fakültesinin çeşitli bölümlerinde [sınıf öğretmenliği(61), okul öncesi öğretmenliği(57), sosyal bilgiler öğretmenliği(44), Türkçe öğretmenliği(35) ve matematik öğretmenliği(31)] öğrenim gören 228 öğretmen adayı oluşturmaktadır. Ölçek geliştirme çalışmalarında örneklem sayısı için farkı araştırmacılar tarafından öneriler sunulmuştur. Belirgin faktörler ortaya çıkarmak için 200 kişilik çalışma grubu yeterli görülmektedir (Kline, 1994). Bu araştırmada öğrencilerin ekran okuma öz yeterlik algı düzeylerini geçerli ve güvenilir olarak ölçmeye olanak tanıyacak bir ölçme aracının geliştirilmesi amaçlanmıştır. Uygulama 2017-2018 eğitim-öğretim yılının güz döneminde yapılmıştır.

\section{Ölçeğin Geliştirilme Sürecinde İzlenen İşlem Basamakları}

Illetişim teknolojilerinin doğasının değişmesi sonucunda internet, twitter, ağ günlüğü, youtube, facebook gibi sosyal ağlar ortaya çıkmıştır (Rowsell ve Walsh, 2011). Günümüzde bireyler iletişim kurmak, bilgi edinmek ve paylaşmak amacıyla bu sosyal platformları yoğun biçimde kullanmaktadır. Teknoloji ve okuryazarlık arasındaki ilişkinin gelişmiş olarak artmaya başlaması sonucunda okuryazarlığın doğası değişmiştir (Marsh ve Singleton, 2009). Günümüzde insanların teknolojiyle yoğun 
etkileşim içinde olmalarından dolayı onların ekran okuma düzeylerini ölçecek ölçme aracı geliştirmek ihtiyaç haline gelmiştir. Bu doğrultuda ilgili literatür taranmış ve konuyla ilgili ölçek geliştirme araştırmaları incelenmiştir. İnceleme sonunda ekran okumaya yönelik farklı yapılar ortaya koyan araştırmalara rastlanmıştır (Gömleksiz ve ark., 2013; Susar-Kırmızı, 2017). Gömleksiz ve ark. (2013) tarafından yapılan araştırmada verilere uygulanan doğrulayıcı faktör analizi sonucunda ölçeğin üç faktörden (anlama, zorluk ve yarar), Susar-Kırmızı (2017) tarafından yapılan araştırmada ise verilere uygulanan doğrulayıc faktör analizi sonucunda ölçeğin beş faktörden (sağlık, okuma ve okuduğunu anlama, kolaylık, sevgi ve etkileyicilik) oluştuğu tespit edilmiştir. Konuyla ilgili yapılan ölçek çalışmalarının incelenmesinin sebebi ekran okuma öz yeterliğine dair teorik olarak net biçimde alt yapıları ortaya koyan ifadeler bulunmamasıdır. Bu açıdan yapılan çalışmalarda ne tür yapıların ortaya konduğu hakkında ön fikir edinilmiştir. Daha sonra literatür taranarak Ekran Okuma Öz Yeterlik Algı Ölçeği (EOÖYAÖ) maddeleri ve göstergeleri belirlenmeye çalışıımıştır. Bu aşamadan sonra 40 maddelik bir madde havuzu oluşturulmuştur. Okuma-yazma (iki) ve ölçme değerlendirme uzmanlarının (bir) görüşlerinin yanı sıra ön uygulama 2016-2017 eğitim-öğretim yılının bahar döneminde gerçekleştirilmiş olup açık ve anlaşılır olmayan, muğlak olan ve birden fazla yargı içeren 12 madde ölçekten çıkarılmıştır. Toplanan veriler üzerinde maddeler yeniden düzenlenmiş ve uygulamaya hazır hale getirilmiştir. Böylece hazırlanan ölçme aracının kapsam geçerliği sağlanmaya çalışılmıştır. Asıl uygulama 2017-2018 eğitim-öğretim yılının güz döneminde gerçekleştirilmiştir. Analiz öncesinde olumsuz maddeler ters çevrilerek puanlama yapılmıştır. Ölçek maddelerinde yer alan ifadeler 5'li likert tipinde (1: benim için hiç uygun değil, 2: benim için uygun değil, 3: kararsızım, 4: benim için uygun, 5: benim için tamamen uygun) derecelendirilmiştir.

\section{Veri Analizi}

Yapı geçerliği için Açımlayıcı Faktör Analizi (AFA) ve Doğrulayıcı Faktör Analizi (DFA) uygulanmıştır. "Açımlayıı faktör analizinde, değişkenler arasındaki ilişkiden hareketle faktör bulmaya yönelik bir işlem; doğrulayıcı faktör analizinde ise değişkenler arasındaki ilişkiye dair daha önce saptanan bir hipotezin ya da kuramın test edilmesi söz konusudur" (Büyüköztürk, 2009:132). Ölçeğin geçerlik güvenirlik çalışmaları için AFA için ölçek toplam 289 öğrenciye dağıtılmıştır. Katıımcıların formu geniş bir zamanda ve rahat bir ortamda doldurabilmeleri için formlar birkaç günlük sürelerle katılımcılara bırakılmıştır. Araştırmacı, katıımcılarla teker teker görüşerek ya da bir katılımcının yardımıyla çevresindeki katıımcıların da formlarını toplamıştır. Bu ölçeklerden aynı katılma derecesini ifade eden, ölçekte yer alan maddelerden herhangi biri boş bırakılan ve normallik varsayımını karşılamayan veri araştırmadan çıkarılmıştır. Sonuçta toplam 228 veri üzerinden işlem yapılmıştır. AFA'da ortaya konulan modelin uygunluğunu test etmek için DFA yapılmıştır. Ölçeğin güvenirliğinin belirlenmesinde Cronbach Alpha güvenirlik katsayısı hesaplanmıştır. Ayrıca madde ayırt ediciliğinin 


\section{Ekran Okuma Öz Yeterlik Ölı̧eği: Geçerlik ve Güvenirlik Çalışması}

saptanması için \%27'lik alt-üst gruplardaki katılımcıların ortalamaları bağımsız örneklemler için t testi ile karşılaştırılmıştır. AFA'dan elde edilen madde-faktör yapısı DFA ile test edilmiştir. AFA güvenirlik katsayıSı ve t testi hesaplamaları SPSS 21.0 programı; DFA ise AMOS 21 programı kullanılarak gerçekleştirilmiştir.

\section{Bulgular}

Bu bölümde EOÖYAÖ geçerlik ve güvenirlik çalışmalarına ilişkin bulgu ve yorumlara yer verilmiştir.

\section{Açımlayıcı Faktör Analizi}

Ölçeğin yapı geçerliğini kanıtlamak amacıyla ilk olarak Açımlayıcı Faktör Analizi (AFA) uygulanmıştır. Verilerin faktör analizine uygun olup olmadığı test edilmiş ve KaiserMeyer-Olkin (KMO) ile Barlett Küresellik testleri sonuçları incelenmiştir. KMO katsayısı, veri matrisinin faktör analizi için uygun olup olmadığını, veri yapısının faktör çıkarma için uygunluğu hakkında bilgi verir. Faktörleştirilebilirlik için KMO'nun .60'dan yüksek çıkması beklenir (Büyüköztürk, 2009). Yapılan analiz sonucunda geliştirilen ölçeğin KMO değeri .788 olarak hesaplanmıştır. Barlett testi ise değişkenler arasında ilişki olup olmadığını korelasyonlar temelinde inceler. Test sonucunun anlamlı çıkması puanların normalliğinin de kanıtı olarak görülebilir (Büyüköztürk, 2009). Yapılan analiz sonucunda Barlett testi sonucu elde edilen Ki-Kare test istatistiği sonucunun anlamlı olduğu görülmüştür $\left(\chi^{2}=\right.$ $790,307, s d=120, p<.001)$. Elde edilen sonuçlar verilerin faktör analizine uygun ve dağılımın normal olduğunu göstermiştir.

Araştırma verileri üzerinde yapılan ilk AFA sonucunda varimax eksen döndürme tekniği sonrasında elde edilen bu faktörlerin bazılarında 3'ten az sayıda madde bulunması (Comrey ve Lee, 1992), bazı maddelerin faktör yüklerinin .40'dan düşük olması, bazı maddelerin .40'ın üzerinde birden fazla faktöre yük vermesi ve bazı maddelerin en yakın faktördeki faktör yükü ile arasında .10' dan düşük olması (Büyüköztürk, 2009) nedeniyle bu maddeler ölçekten çıkarılarak AFA tekrarlanmıştır. Illk yapılan açımlayıcı faktör analizi sonucunda 25 maddeden oluşan 7 faktörlü ölçek ortaya çıkmıştır fakat doğrulayıcı faktör analizi sonucunda değerler (GFI=.886, AGFI=.862, CFI=.825, NFI=.707) uygun çıkmadığı için modifikasyon değerleri tutarlı olmayan maddeler ölçekten çıkartılmıştır. Yapılan analizler sonucunda ölçekte geriye kalan 16 maddenin 4 faktörde toplandığı görülmüştür. Bu faktörlere ilişkin özdeğerler aşağıdaki şekilde gösterilmiştir. Ölçeğe yönelik scree-plot grafiği de ölçeğin dört faktörlü yapısına yönelik kanıt sunmaktadır. Ölçeğin scree-plot grafiği Şekil 1'de yer almaktadır. 


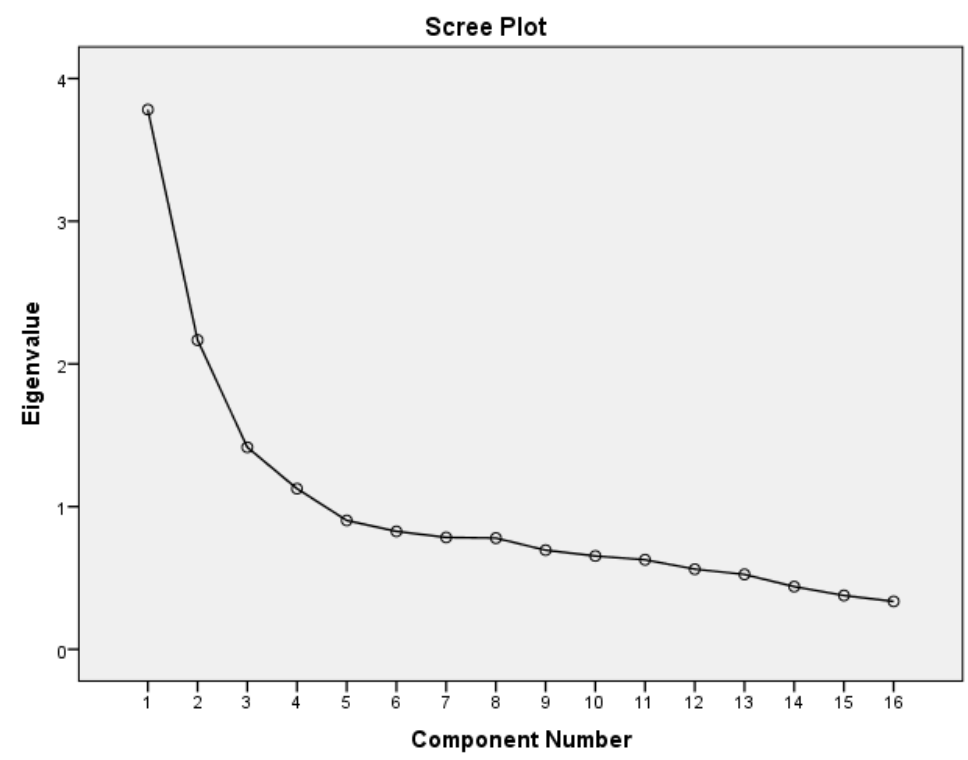

Şekil 1. Yamaç-Birikinti (Scree Plot) Grafiği

Yukarıdaki yamaç birikinti grafiğindeki kırılma noktaları incelendiğinde ölçekte özdeğeri bir ve birden fazla olan dört faktör olduğu görülmektedir. Hutcheson ve Sofroniou (1999), özdeğeri 1 veya 1'den büyük olan faktörlerin önemli faktör olarak nitelendirilmesi gerektiğini söylemektedir.

Ölçeğin ilk boyutunu 6 maddeden oluşan, öz değeri 2.56 ve açıkladığı varyans \%16.04 olan "kullanışııık" oluşturmuştur. Ölçeğin ikinci boyutu yine 3 maddeden oluşan, öz değeri 2.07 ve açıkladığı varyans \%12.94 olan "anlama"dır. Üçüncü boyut 3 maddeden oluşan, öz değeri 2.04 ve açıkladığı varyans \%12.75 olan "sayfayı yönetme" ve dördüncü boyut ise 4 maddeden oluşan, öz değeri 1.81 ve açıkladığı varyans \%11.32 olan “göz sağlığı”dır. Ölçeğin toplamda \%53.07'sini açıklaması yeterli bir oran olarak düşünülmektedir. Büyüköztürk (2009)'e göre tek faktörlü ölçeklerde açıklanan varyansın \%30 olması yeterli görülürken çok faktörlü ölçeklerde açıklanan varyansın daha fazla olması beklenir. Maddelerin faktörlere dağılımları, faktör yükleriyle birlikte Tablo 1'de sunulmuştur.

Tablo 1. Ekran Okuma Öz Yeterlik Algı Ölçeği

\begin{tabular}{|c|c|c|c|c|}
\hline \multirow[t]{2}{*}{ Maddeler } & \multicolumn{2}{|c|}{ Faktör Yük Değerleri } & \multirow[b]{2}{*}{ Faktör 3} & \multirow[b]{2}{*}{ Faktör 4} \\
\hline & Faktör 1 & Faktör 2 & & \\
\hline $\begin{array}{l}\text { 15.Ekrandaki içeriği görsel, ses, animasyon vb. } \\
\text { unsurlarla ilişkilendirerek anlamlandırırım. }\end{array}$ & .683 & & & \\
\hline $\begin{array}{l}\text { 3.Ekran okumanın materyalleri depolama } \\
\text { kapasitesinden yararlanırım. }\end{array}$ & .665 & & & \\
\hline $\begin{array}{l}\text { 17.Ekran okumada metin içi ayrıntıları (ekranda ve } \\
\text { ekran dışında kalan içerik) hatırlayabilirim. }\end{array}$ & .664 & & & \\
\hline $\begin{array}{l}\text { 1.Ekran okuma sürecinde okuma amacımdan (oyun, } \\
\text { sosyal paylaşım vb. sitelere girme) uzaklaşırım. }\end{array}$ & .623 & & & \\
\hline $\begin{array}{l}\text { 12.Ekran okuma sürecinde "bul” komutu sayesinde } \\
\text { aradığım bilgiler olup olmadığını değerlendirebilirim. }\end{array}$ & .574 & & & \\
\hline $\begin{array}{l}\text { 10.Ekran okuma sürecinde sayfalarda gezinmek ve } \\
\text { istenilen bölüme atlamak yorucudur. }\end{array}$ & .452 & & & \\
\hline
\end{tabular}




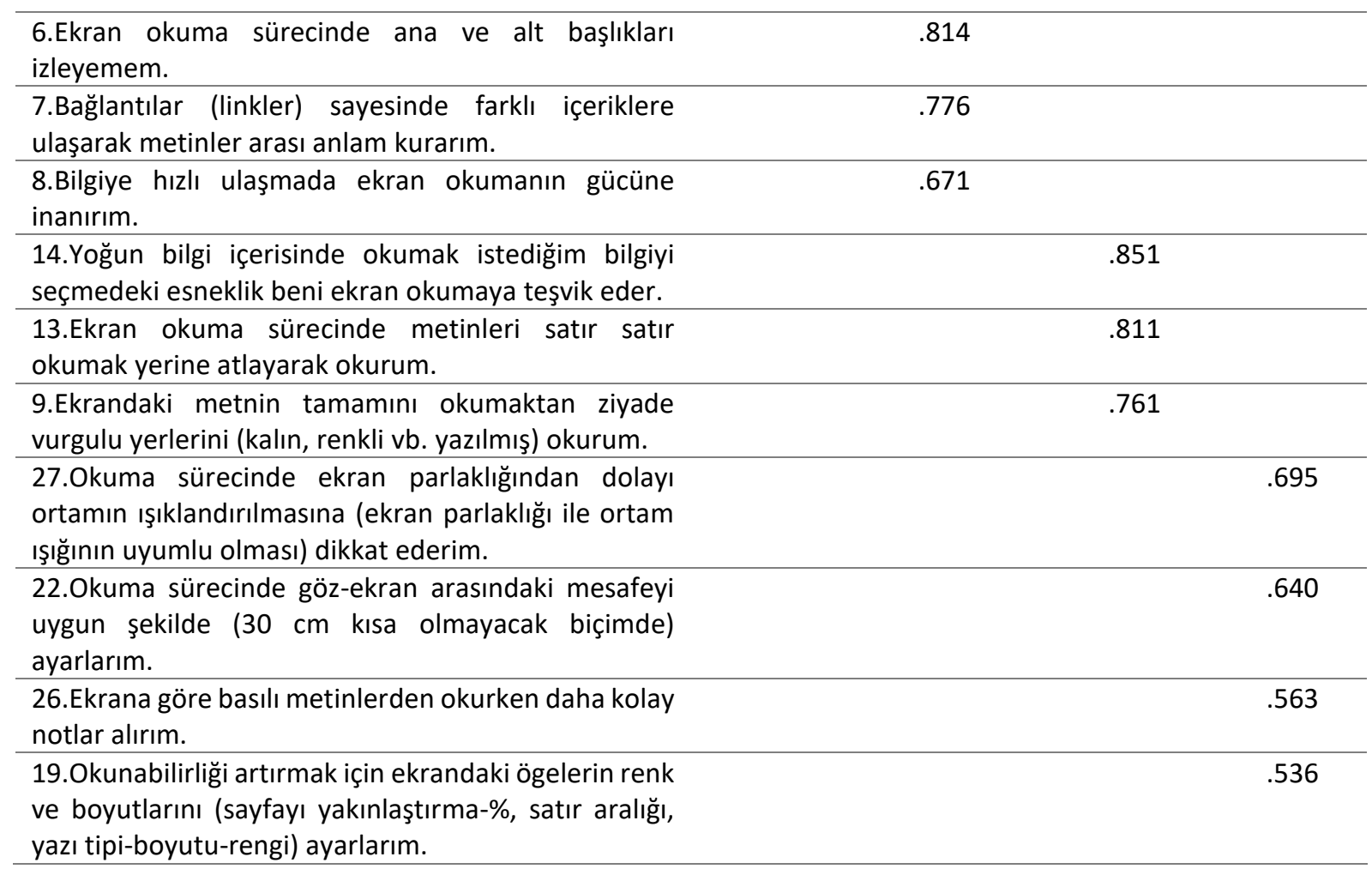

Tablo 1'de görüldüğü gibi ölçekte yer alan maddelerin faktör yükleri ,851 ile .452 arasında değişmektedir. Büyüköztürk (2009)'e göre faktör yük değerinin, 0.45 ya da daha yüksek olması seçim için iyi bir ölçüdür. Bu faktörde yer alan maddeler incelenerek "kullanışlıık" olarak adlandırılmıştır. Üç maddeden oluşan ikinci faktörde bulunan maddelerin yük değeri .814 ilâ .671 aralığındadır. Bu faktör “anlama” olarak adlandırılmıştır. Üç maddenin yer aldığı üçüncü faktöre ait maddelerin yük değeri .851 ilâ .761 arasındadır. Bu faktör "sayfayı yönetme" olarak adlandırılmıştır. Ortamın ışıklandırılması ve göz hareketleriyle ilgili maddelerin nitelenmesinde "göz sağlı̆ı̆" ifadesi kullanılmıştır. Dört maddenin yer aldığı dördüncü faktöre ait maddelerin yük değerleri ise .695 ilâ .536 arasındadır. AFA'da elde edilen değerlerin ve ortaya konulan yapının uygunluğunu test etmek için DFA yapılmışır. 
Yapılan DFA'da elde edilen faktör dağılımları Şekil 2'de verilmiştir.

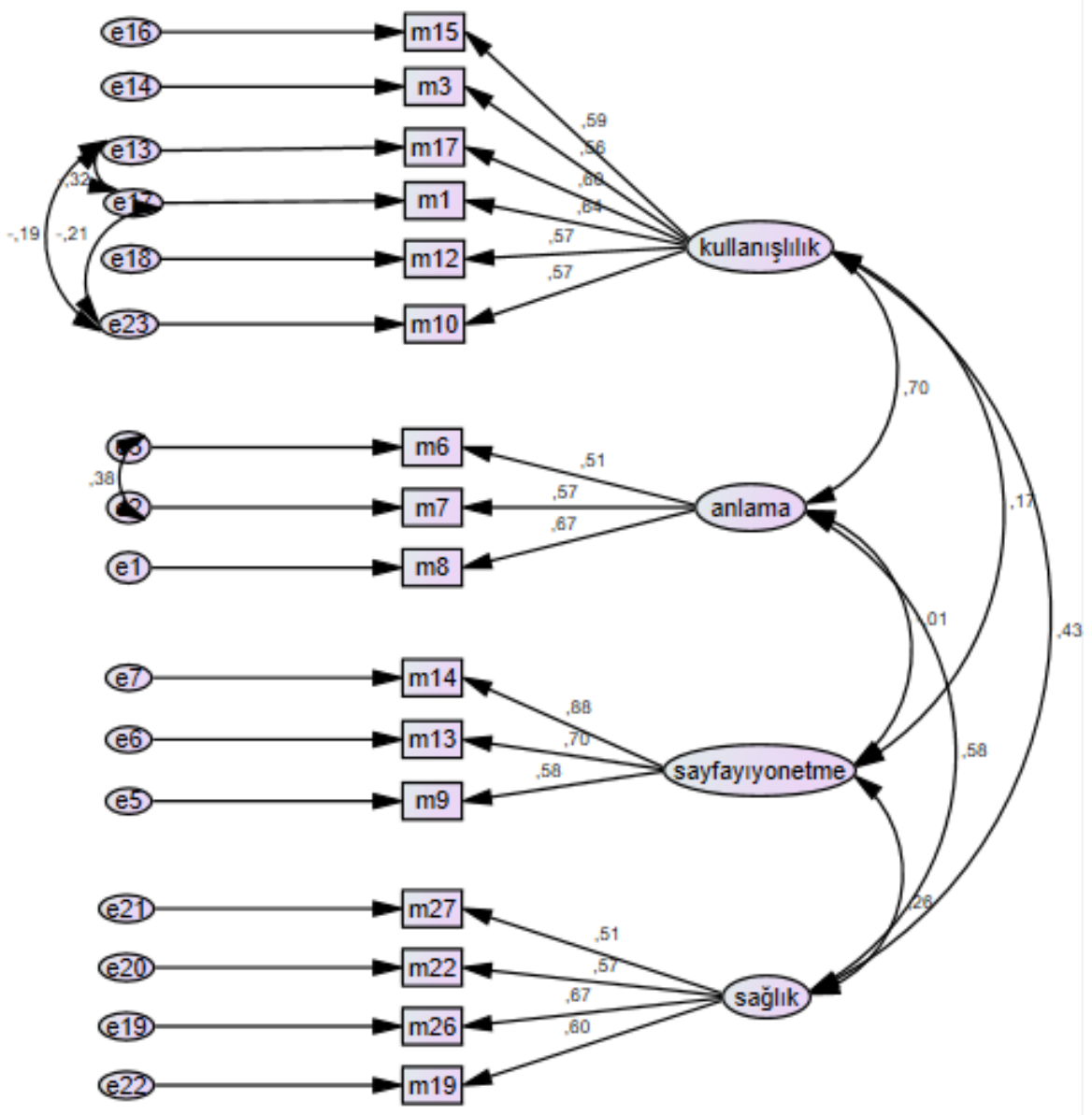

Şekil 2. Dört Faktörlü Modele ilişsin DFA

Ekran okuma ölçeğinin 16 madde ve dört faktörden oluşan yapısı DFA yoluyla test edilmiştir. DFA ile öncelikle 16 madde ve dört faktörden oluşan modelin uyum indeksleri incelenmiştir. DFA'da "kullanışlılık" faktör maddelerinin sırasıyla .59, .56, .69, .64, .57 ve .57, "anlama" faktör maddelerinin sırasıyla $.51, .57$ ve .67 , "sayfayı yönetme" faktör maddelerinin sırasıyla $.88, .70$ ve .58 ile "göz sağlı̆ıı" faktör maddelerinin $.51, .57, .67$ ve .60 standart çözüme sahip olduğu görülmektedir. İlk olarak modelde orijinal yapı doğrulayıcı faktör analizine tabi tutularak uyum istatistikleri ve modifikasyon indeksleri incelenmiştir. Bunun yanında 16 madde ve dört faktörlü yapının t değerleri incelenmiştir. "Kullanışlılık" faktör maddelerinin t değerleri sırasıyla 7.26, 7.06, 6.49, 12.25, 11,22 ve 11,22, "anlama" faktöründekilerin sırasıyla 11.22, 12.25 ve 10.25, "sayfayı yönetme" faktöründekilerin sırasıyla 3.06, 2.96 ve 2.91 ile "göz sağ|ığı" faktöründekilerin sırasıyla 11.22, 12.25, 10.25 ve 12.25 olduğu tespit edilmiştir. Parametre tahminleri, eğer $t$ değerleri 1.96'yı aşarsa .05 düzeyinde; 2.56 'yı aşarsa .01 


\section{Ekran Okuma Öz Yeterlik Ölçeği: Geçerlik ve Güvenirlik Çalışması}

düzeyinde anlamlıdır (Çokluk, Şekercioğlu ve Büyüköztürk, 2010). Bu çerçevede tüm maddelerin .01 düzeyinde anlamlı olduğu görülmektedir.

DFA ile test edilen diğer değerler ise modelin uyum indeksleridir. İncelenmesi gereken değerlerden birisi $\mathrm{p}$ değeridir. Bu araştırmada Ki-Kare değerinin $\left(\chi^{2}=120.609, \mathrm{df}=108, \mathrm{p}<0.001\right) . \chi^{2}$ uyum istatistiği değeri $\chi^{2} / \mathrm{sd} \leq 2$ ise mükemmel uyum anlamına gelmektedir (Tabachnick ve Fidell, 2007). Geliştirilen ölçekte bu değerin 1.27 olduğu görülmektedir. Uyum indeksi değerleri ise RMSEA $=.023, \mathrm{GFI}=.93, \mathrm{CFI}=.98, \mathrm{AGFI}=.92, \mathrm{NFI}=.90, \mathrm{SRMR}=.064$ olarak bulunmuştur. Uyum indekslerinde $\mathrm{GFI}, \mathrm{CFI}, \mathrm{AGFI}, \mathrm{NFI}$ için >.90; RMSEA için <.05 ve SRMR için <.08 ölçüt (Hu ve Bentler, 1999, Akt. Kabakçı ve Korkut-Owen, 2010) olarak alınmıştır. Bu uyum indeksi değerleri açısından model ve gözlenen veri arasında uyum olduğu ve önerilen modelin iyi düzeyde uyum gösterdiği anlaşılmaktadır.

\section{Güvenirlik Analizi}

Güvenirlik analizi geçerliği ortaya konulan EOÖYAÖ güvenirlik çalışmalarında Cronbach-Alfa iç tutarlık ve test-tekrar test güvenirlik katsayıları hesaplanmıştır. Her bir faktöre ait hesaplanan Cronbach-Alfa katsayıları Tablo 2'de verilmiştir.

Tablo 2. EOÖYAÖ Alt Faktörlerine Iliş̧kin Güvenirlik Sonuçları

\begin{tabular}{lc}
\hline Faktörler & Cronbach-Alfa İç Tutarlık Katsayısı ( $\boldsymbol{\alpha})$ \\
\hline Kullanışııı & .769 \\
\hline Anlama & .715 \\
\hline Sayfayı Yönetme & .657 \\
\hline Göz Sağlığı & .748 \\
\hline Toplam & .758 \\
\hline
\end{tabular}

Ölçeğin ölçmek istediği özelliği (ekran okuma öz yeterliği) ne derece doğru ölçtüğünü başka bir ifadeyle ölçeğin güvenilirliğini belirlemek amacıyla Cronbach Alfa güvenirlik katsayısı hesaplanmıştır. Bu katsayı; 0,60 ile 0,80 arasında olduğunda ölçek “oldukça güvenilir”, 0,80 ile 1,00 arasında olduğunda ise "yüksek derecede güvenilir"dir (Akgül ve Çevik, 2003). Cronbach Alfa değeri birinci faktör için .769; ikinci faktör için .715; üçüncü faktör için .657; dördüncü faktör için .748, ölçeğin tümü için .758 olarak hesaplanmıştır. Ölçek dört hafta sonra 71 öğrenciye tekrar uygulanmıştır. Her iki uygulamadan elde edilen puanlar arasındaki Pearson korelasyon katsayısı .825 olarak hesaplanmıştır. Bu sonuç ölçeğin uygulamadan uygulamaya tutarlı sonuçlar verdiğinin kanıtıdır.

\section{Madde Analizi}

EOÖYAÖ madde analizi çalışmalarında 4 faktörde yer alan maddelerin düzeltilmiş maddetoplam korelasyonu hesaplanmış ve maddelerin alt ve üst \%27'lik grupları ayırt edip etmediğini sınamak için t-testi kullanılmıştır. Ölçeğin madde analizine ilişkin bulgular Tablo 3'te gösterilmiştir. 
Tablo 3. EOÖYAÖ Madde Analizi Sonuçları

\begin{tabular}{|c|c|c|c|}
\hline & Maddeler & Düzeltilmiş Madde-Toplam Korelasyonu ${ }^{1}$ & t (Alt \%27-Üst \%27) \\
\hline \multirow[t]{6}{*}{ Kullanışlılık } & 15 & .40 & -8.35 \\
\hline & 3 & .39 & -7.26 \\
\hline & 17 & .36 & -7.76 \\
\hline & 1 & .34 & -5.67 \\
\hline & 12 & .42 & -8.19 \\
\hline & 10 & .42 & -8.01 \\
\hline \multirow[t]{3}{*}{ Anlama } & 6 & .35 & -7.69 \\
\hline & 7 & .49 & -10.16 \\
\hline & 8 & .46 & -9.62 \\
\hline \multirow[t]{3}{*}{ Sayfayı Yönetme } & 14 & .29 & -6.22 \\
\hline & 13 & .23 & -5.75 \\
\hline & 9 & .16 & -3.95 \\
\hline \multirow[t]{4}{*}{ Göz Sağlığı } & 27 & .38 & -7.26 \\
\hline & 22 & .32 & -5.72 \\
\hline & 26 & .26 & -4.81 \\
\hline & 19 & .38 & -7.28 \\
\hline
\end{tabular}

Madde toplam korelasyonu yorumlanırken değeri .30 ve üzerinde olan maddeler, ölçülecek özelliği ayırt etme açısından yeterli kabul edilmektedir (Büyüköztürk, 2009). Ayrıca alt ve üst \%27'lik gruplar için hesaplanan t değerlerinin anlamlı ( $p<.001)$ olduğu görülmektedir. Bu sonuçlar ölçekte yer alan maddelerin geçerliklerinin yüksek olduğu ve ekran okuma öz yeterlilikleri bakımından öğrencileri ayırt edebildiği şeklinde yorumlanabilir.

\section{Tartışma ve Sonuç}

Bu çalışmada, öğretmen adaylarının ekran okumaya yönelik öz yeterlik algılarını belirlemeye ilişkin bir ölçeğin geliştirilmesi amaçlanmıştır. Çalışmanın örneklemini, bir devlet üniversitesinin eğitim fakültesinin çeşitli bölümlerinde öğrenim gören öğretmen adayları oluşturmaktadır. EOÖYAÖ’yü geliştirmek amacıyla, konuyla ilgili literatür taraması yapılmış ve ölçekte yer alabileceği düşünülen 40 maddelik bir taslak form hazırlanmıştır. Uzman görüşleri doğrultusunda, kapsama uygun olmayan ve açık olmayan (muğlak) ifadeler düzeltilerek bazı maddeler ölçekten çıkartılmıştır. Bu şekilde hazırlanan taslak form 5'li likert tipinde derecelendirilmiştir.

EOÖYAÖ’nün AFA sonucu madde analizi çalışmalarında madde-toplam korelasyonlarına bakılmıştır. Madde-toplam puan korelasyon değeri $.45^{\prime}$ in altında olan herhangi bir maddeye rastlanılmamıştır. Toplam varyansın \%53.07'sini açıklayan 16 madde ve 4 faktörden oluşan bir yapı elde edilmiştir. Birinci faktörde 6, ikinci faktörde 3, üçüncü faktörde 3 , dördüncü faktörde ise 4 madde yer almaktadır. Birinci faktör "kullanışlıık", ikinci faktör "anlama", üçüncü faktör "sayfayı yönetme" ve dördüncü faktör “göz sağlığı” olarak isimlendirilmiştir. EOÖYAÖ’ye ilişkin elde edilen yapının doğruluğu DFA ile test edilmiştir. DFA'dan elde edilen uyum indeks değerleri incelenerek verilerin model ile kabul edilebilir düzeyde uyumlu olduğu görülmüştür. Özetle, dört alt boyuttan oluşan ölçeğin geçerli bir yapıda olduğu tespit edilmiş ve DFA sonucu da modelin uyumlu olduğunu göstermiştir. 


\section{Ekran Okuma Öz Yeterlik Ölı̧eği: Geçerlik ve Güvenirlik Çalışması}

Ölçeğin güvenirliğini belirlemek için Cronbach-Alfa iç tutarlık ve test-tekrar test güvenirlik katsayıları hesaplanmıştır. Bulunan değerlere göre ölçeğin güvenilir olduğu sonucuna varılmıştır. Madde analizi için de her maddenin düzeltilmiş madde-toplam korelasyonu hesaplanmış ve maddelerin alt ve üst \%27'lik grupları ayırt edip etmediğini sınamak için t-testi kullanılmıştır. Bu sonuçlara göre de ölçekte yer alan maddelerin geçerli olduğu ve ekran okuma öz yeterlik algıları bakımından öğrencileri ayırt edebildiği saptanmıştır.

Ekran okumaya yönelik öz yeterlik (Gömleksiz ve ark., 2013) ve tutum (Susar-Kırmızı, 2017) bakımından geliştirilen ölçekler bulunmaktadır. Gömleksiz ve ark. (2013) tarafından yapılan araştırmada AFA sonucunda anlama, zorluk ve yarar boyutlarından oluşan EOÖYAÖ’nün güvenirlik katsayısı .758 olarak hesaplanmıştır. Susar-Kırmızı (2017) tarafından yapılan araştırmada AFA sonucunda sağlık, okuduğunu anlama, kolaylık, sevgi ve etkileyicilik faktörlerinden oluşan 29 maddelik ekran okumaya yönelik tutum ölçeği oluşturulmuştur. Bu çalışmanın alt faktörlerinde yer alan maddeler, ilgili araştırmaların alt boyutlarındaki maddeler ile benzerlik göstermesine karşın; elde edilen faktör yapıları ve faktörlerin isimlendirilmesi bakımından farklılaşmaktadır.

Elektronik metinlerin geleneksel basılı metinlerden birtakım farklılıkları bulunmaktadır. "Geleneksel metinlerde alfabenin yanı sıra resimler, şekil ve grafikler kullanılmaktadır. Ancak, dijital ortam ile bunlara ses, görüntü, sesli görüntü, animasyonlar ve semboller eklenmektedir. Dolayısı ile elektronik metin kavramı sadece metinlerle sınırlı kalmayıp aynı zamanda sözlü, yazılı, görsel, işitsel ve çok yönlü niteliğe dönüşmektedir" (Landow, 1992, akt. Maden, 2012, s.2). Dolayısıyla bireylerin ekran okumaya yönelik öz yeterliklerini geliştirmek için en önemli görev öğretmenlere düşmektedir. Bunun için öncelikle öğretmenlerin yeni okuryazarlık anlayışını derslerine uygulamaları için konu ile ilgili yeterliliklere sahip olmaları gerekmektedir. Yapılan analizler sonucunda geçerli ve güvenilir olduğu saptanan ölçek ile öğretmen adaylarının ekran okuma öz yeterlik algıları lisans eğitimlerinde belirlenebileceği düşünülmektedir. Ekran okuma becerisini etkileyen değişkenler tespit edilebilir. Örneğin cinsiyet, sınıf düzeyi, bölüm gibi değişkenlerin yanı sıra metin uzunluğu, yazı tipi puntosu tercihi, sosyal ağlara üyelik vb. değişkenlerin etkisi de araştırılabilir. Bu yönde yapılacak araştırmalar öğretmen adaylarının basılı metinlerin yanı sıra ekran okuma tercihlerine farklı bakış açılarıyla yorum getirebilir.

\section{Kaynaklar}

Ahmed, F., Borodin, Y., Soviak, A., Islam, M., Ramakrishnan, I. \& Hedgpeth, T. (2012). Accessible skimming : Faster screen reading of web pages. In 25th Annual ACM Symposium on User Interface Software and Technology (UIST), 367-378. Doi: 10.1145/2384916.2384998.

Akgül, A. \& Çevik, O. (2003). Istatistiksel analiz teknikleri SPSS'te işletme yönetimi uygulamaları. Ankara: Emek Ofset.

Aypay, A. (2010). Genel öz yeterlik ölçeği'nin (GÖYÖ) Türkçe'ye uyarlama çalışması. Inönü Üniversitesi Eğitim Fakültesi Dergisi, 11(2), 113-131. 
Başaran, M. (2014). Sınıf seviyesinde ekrandan ve kâğıttan okumanın okuduğunu anlama, okuma hızı ve metne karşı geliştirilen tutum üzerindeki etkisi. Uşak Üniversitesi Sosyal Bilimler Dergisi, 7(2), 248-268.

Baştuğ, M. \& Keskin, H.K. (2012). Okuma becerilerinin okuma ortamı açısından karşılaştırılması: Ekran mı kâğıt mı? Atatürk Üniversitesi Sosyal Bilimler Enstitüsü Dergisi, 16(3), 73-83.

Burk, R. (2001). E-book devices and the marketplace: In search of customers. Literary Hi Tech, 19, 325-331.

Büyüköztürk, Ş. (2009). Veri analizi el kitabı (10. Baskı). Ankara: Pegem Akademi.

Carusi, A. (2006). Textual practitioners: a comparison of hypertext theory and phenomenology of reading. Arts and Humanities in Higher Education, 5(2), 163-180.

Chou, I. C (2011). Understanding on-screen reading behaviors in academic contexts: A case study of five graduate English-as-asecond-language students. Computer Assisted Language Learning, 25(5), (2011),1-23.

Coiro, J. 2003. "Reading comprehension on the internet: Expanding our understanding of reading comprehension to encompass new literacies. The Reading Teacher 56(6), 458- 464.

Çokluk, Ö., Şekercioğlu, G. \& Büyüköztürk, Ş. (2010). Sosyal bilimler için çok değişkenli istatistik SPSS ve LISREL uygulamaları. Ankara: Pegem Akademi Yayıncılık.

Comrey, A. L. \& Lee, H. B. (1992). A first course in factor analysis (2. edition). New Jersey: Lawrence Erlbaum Associates.

Dağtaş, A. (2013). Öğretmenlerin basılı sayfa ve ekrandan okuma tercihleri ile eğitimde elektronik metin kullanımına yönelik görüşleri. International Periodical For The Languages, Literature and History of Turkish or Turkic, 8(3), 137-161.

Duran, E. \& Alevli, O. (2014a).Ekrandan okumanın sekizinci sınıf öğrencilerinde anlamaya etkisi. Okuma Yazma Eğitimi Araştırmaları, 2(1), 1-11.

Duran, E. \& Alevli, O. (2014b). Öğrenci görüşleri: Dijital metin mi basılı metin mi? International Journal of Language Academy, 2(2), 110-126.

Dyson. M. C. \& Haselgrove, M. (2001). The influence of reading speed and line length on the effectiveness of reading form screen. International Journal of Human-Computer Studies, 54, 585-612. DOI: 10.1006/ijhc.2001.0458.

Ekinci, N. (2015). Öğretmen adaylarının öğrenme yaklaşımları ve öğretmen öz yeterlik inançları arasındaki ilişki. Hacettepe Üniversitesi Eğitim Fakültesi Dergisi, 30(1), 62-76.

Ercan, A.N. \& Ateş, M. (2015). Ekrandan okuma ile kağıttan okumanın anlama düzeyi açısından karşılaştırılması. International Periodical For The Languages, Literature and History of Turkish or Turkic, 10(7), 395-406.

Ertem, I.S. \& Özen, M. (2014). Metinleri ekrandan okumanın anlam kurma üzerine etkisi. International Journal of Social Science, 24, 319-350.

Gibson, C. \& Gibb, F. (2011). An evaluation of second generation ebook readers. The Electronic Library, 29(3), 303-319.

Gömleksiz, M.N., Kan, A.Ü. \& Fidan, E.K. (2013). Öğretmen adaylarının ekran okuma özyeterlik düzeylerine ilişkin görüşleri. Erzincan Üniversitesi Eğitim Fakültesi Dergisi, 15(2), 138-159.

Güneş, F. (2009). Hızlı okuma ve anlamı yapılandırma. Ankara: Nobel Yayın Dağıtım.

Güneş, F. (2010). Öğrencilerde ekran okuma ve ekranik düşünme. Mustafa Kemal Üniversitesi Sosyal Bilimler Enstitüsü Dergisi, 7(14), 1-20.

Hsieh, P., \& Dwyer, F. (2009). The instructional effects of online reading strategies and learning styles on student academic achievement. Educational Technology ve Society, 12(2), 36-50.

Hutcheson, G. D. \& Sofroniou, N. (1999). The multivariate social scientist: Introductory statistics using generalized linear models. London: Sage Publications. 


\section{Ekran Okuma Öz Yeterlik Ölçeği: Geçerlik ve Güvenirlik Çalışması}

İleri-Aydemir, Z., Öztürk, E. \& Horzum, M.B. (2013). Ekrandan okumanın 5. sınıf öğrencilerinin bilgilendirici ve öyküleyici metin türünde okuduğunu anlama düzeylerine etkisi. Kuram ve Uygulamada Eğitim Bilimleri, 13(4), 2263-2276.

JAWS, (2011). Screen reader from Freedom Scientific. Retrieved from July, 19, 2008, http://vala.org.au/vala2004/ 2004pdfs/32Merci.PDF.

Kabakçı, Ö.F. \& Korkut-Owen, F. (2010). Sosyal duygusal öğrenme becerileri ölçeği geliştirme çalışması. Eğitim ve Bilim, 35(157), 152-166.

Karasar. Niyazi. (2005). Bilimsel araştırma yöntemi. Ankara. Nobel Yayın Dağıtım.

Kellner, D. (2000). New technologies/New literacies: Reconstructing education for the new millennium. Teacher Education, 11(3), 245-265.

Kline, P. (1994). An easy guide to factor analysis. New York: Routledge.

Kurudayıoğlu, M. \& Tüzel, S. (2010). 21. yy. okuryazarlık türleri, değişen metin algısı ve Türkçe öğretimi. TÜBARXXVIII, 283-293.

Kuru, O., Kaşkaya, A. \& Calp, Ş. (2017). İlkokul 4. sınıf öğrencilerinin kâğıttan ve ekrandan okuduğunu anlama becerilerinin sınanması; Öğretmen ve öğrenci görüşleri. Sosyal Bilimler Dergisi, 7(13), 70-84.

Macit, İ. \& Demir, M.K. (2016a). Dördüncü sınıf öğrencilerinin ekran okuma becerilerinin değerlendirilmesi. International Periodical for the Languages, Literature and History of Turkish or Turkic, 11(3), 16471664.

Macit, İ. \& Demir, M.K. (2016b). İlkokul dördüncü sınıf öğrencilerinin kâğıttan okuma becerileri ile ekran okuma tercih düzeyleri arasındaki ilişkinin incelenmesi. Trakya Üniversitesi Sosyal Bilimler Dergisi, 18(1), 331-346.

Maden, S. (2012). Ekran okuma türleri ve Türkçe öğretmeni adaylarının ekran okumaya yönelik görüşleri. Dil ve Edebiyat Eğitimi Dergisi, 1(3), 1-16.

Maden, S. \& Maden, A. (2016). Ortaöğretim öğrencilerinin ekran okumaya yönelik tutumları. Uluslararası Türkçe Edebiyat Kültür Eğitim Dergisi, 5(3), 1305-1319.

Marsh, J. \& Singleton, C. (2009). Literacy and technology: Questions of relationship. Journal of Research in Reading, 32(1), 1-5.

Mercieca, P. (2004). E-book acceptance: What will make user read on screen? Paper presented in VALA conference. Retrieved from March 19, 2008, http://vala.org.au/vala2004/2004pdfs/32Merci.PDF.

Muter, P. \& Maurutto, P. (1991). Reading and skimming from computer screens and books: The paperless office revisited? Behaviour \& Information Technology, 10(4), 257-266. Retrieved from http://www.psych.utoronto.ca/users/muter/pmuter2.htm.

O'Hara, K. \& Sellen, A. (1997). A comparison of reading paper and online documents. Processing CHI '97. Conference on Human Factors in Computer Systems, 335-34, Atlanta, GA. Retrieved from November 12, 2017 http://www.xrce.xerox.com/publis/camtrs/html/epc-1997-101.htm.

Rose, E. (2011). Continuous partial attention teaching and learning in the age of interruption. Antistasis, 1(2), 1719.

Rowsell, J. \& Walsh, M. (2011). Rethinking literacy education in new times: Multimodality, multiliteracies \& New literacies. Brock Education, 21(1), 53-62.

Russo, A. \& Watkins, J. (2008). New literacy new audiences: Social media and cultural institutions. In S. Dunn, S. Keene, G. Mallen, \& J. P. Bowen (Eds.), EVA London 2008 Conference Proceedings, 22-24 July (pp. 225239. Australia.

Spencer, C. (2006). Research on learners' preferences for reading from a printed text or from a computer screen. Journal of Distance Education Reveu De L'education A Distance Spring/Printemps, 21, 33-50. 
Susar-Kırmızı, F. (2017). Ekrandan okumaya yönelik tutum ölçeğinin (EKYÖTÖ) geliştirilmesi: Geçerlilik ve güvenirlik çalışması. International Journal of Languages' Education and Teaching, 5(1), 286-301.

Sweller, J. (1988). Cognitive load during problem solving: Effects on learning. Cognitive Science, 12, 257-285.

Tabachnick, B. G. \& Fidell, L. S. (2007). Using multivariate statistics (5. edition). Boston: Allyn and Bacon.

Ulu, H. (2017). Öğretmen adaylarının e-kitap kavramına ilişkin metaforik algıları. International Journal of Languages' Education and Teaching, 5(4), 542-555.

Woody, W. D., Daniel, D. B. \& Baker, C. A. (2010). E-books or textbooks: Students prefer textbooks. Computers ve Education, 55, 945-948.

Yaman, H. \& Dağtaş, A. (2013). Ekrandan okumanın okumaya yönelik tutuma etkisi. Eğitimde Kuram ve Uygulama, 9(4), 314-333.

Yıldırım, F. \& illhan, i.Ö. (2010). Genel özyeterlilik ölçeği Türkçe formunun geçerlilik ve güvenilirlik çalışması. Türk Psikiyatri Dergisi, 21(4), 301-308.

\section{Extended Abstract \\ Introduction}

The same behavior could be seen among other students with higher engagement in on-screen reading. When they want to read carefully, they prefer to read hardcopy materials (Chou, 2011). Some researchers suggest digital texts, specifically hypertexts, motivate students to engage in individual extensive reading (Coiro, 2003). Readers today need to overcome old reading habits related to traditional print-based texts while, at the same time, acquiring and exploiting new, innovative approaches that take into account the nature of electronic texts (Chou, 2011). According to Carusi (2006), the gist of these studies is that the reading practices of hypertext readers become increasingly fragmentary, that they are easily distracted by surface features. O'Hara \& Sellen (1997), through their observation of the reading processes of readers using either online or paper texts, found that the benefits of hard copy far outweigh those of online textual displays. They claim that major advantages paper texts offer include supporting annotation while reading as well as quick navigation through and flexibility of spatial layout. These allow readers to deepen their understanding of the text, extract a sense of its structure, plan for writing, cross-refer to other documents, and interweave reading and writing. Other key advantages that screen-based texts are thought to provide include the options of using easier-to-read large font sizes (Mercieca, 2004). Whatever the specific purpose of reading may be, people are often faced with large volumes of information that they need to process. Cognitive overload is a fundamental problem that arises while processing a large volume of information in web pages (Sweller, 1988). Eyestrain is one of the commonly reported reasons for print preference. Participants in Mercieca's (2004) study, responded that reading from a screen after a while made them suffer from eye strain. Thus, students reading print texts are more likely to continue reading at one sitting than students using screen-based texts. From this point, in this study, it was aimed to develop a measurement tool to determine pre-service classroom teachers perception of self-efficacy for screen reading.

\section{Method}

The scale was applied to 228 students in education faculty at state üniversity. As a result of factor analysis, four factors have emerged consist of 16 items and account for the $53.07 \%$ of the total variance. The development of the scale has also been included in the first scan of the literature (Carusi, 2006; Duran \& Alevli, 2014; Dyson \& Haselgrove, 2001; Gibson \& Gibb, 2011; Güneş, 2010; Mercieca, 2004; Muter \& Maurutto, 1991; O'Hara \& Sellen, 1997; Sweller, 1988; Woody, Daniel \& Baker, 2010). The literature was reviewed in order to determine what various indicators could reveal about reading and writing teaching. 40-point in line with the relevant literature was created from an item pool. The form that emerged was analyzed and evaluated by two experts. In the study, a draft of the scale which contained 28 items was composed based on both reviews of the extant literature and the opinions of experts of this area.

\section{Findings, Discussion and Results}

At the end of EFA, we identified that the scale had a 4 factored structure, which explains \%53.07 of the total variance. As a result of the CFA conducted, consistency index values were identified and the 4 factor structured scale, recognized as made up of 16 items, was verified as a model. The Cronbach's alpha coefficient sub-dimensions of the scale were $.769, .715, .657$ and .748 . This value met the .60 criterion for reliability (Akgül \& Çevik, 2003). I applied CFA to assess whether the second group's data would justify the EFA results obtained from 16 items and 4 factors. Fit indexes of the obtained model were examined in the CFA performed, and it was observed that the CAES's fit index values were as follows: $\chi 2$ /sd=1.27, GFI=.93, $\mathrm{AGFI}=.92, \mathrm{CFI}=.98, \mathrm{NFI}=.90$, 
RMSEA $=.023$. The acceptable and perfect fit values, which were examined in order to test the adequacy of the model; also shown are the fit index values obtained from the CFA, as well as the relevant results. The findings have shown that scale is valid and reliable to measure attitudes. During the studies of item analysis, corrected item-total correlation of the items within 4 factors was calculated and the t-test was used to determine if these items discriminate the $27 \%$ of the upper groups and the $27 \%$ the lower groups. These results can indicate that the items in the scale have a validity rate, and it can discriminate between students with regard to their selfefficacy of screen reading.

In this study, a new scale was developed to measure self-efficacy towards screen reading. When the findings of the study were generally evaluated, appropriate qualities could be found. At the end of the study, a valid and reliable scale was developed at an acceptable level. It has been anticipated that the scale may constitute an important reference in terms of the work to be carried out. Through this scale, the self-efficacy of undergraduate students towards screen reading can be determined. Researchers interested in the subject may plan various studies on the application of scale.

\section{EK 1}

\section{EKRAN OKUMA ÖZ YETERLIK ALGI ÖLÇEĞi}

Değerli öğretmen adayı;

Aşağıda ekran okuma becerilerine dönük 16 ifade yer almaktadır. Bu ifadeleri dikkatlice okuduktan sonra, size uygunluk derecelerine göre 1'den 5'e kadar olan numaralardan birini işaretleyerek görüşünüzü belirtiniz. Lütfen sadece bir seçeneği işaretleyiniz ve boş bırakmamaya özen gösteriniz.

\begin{tabular}{|c|c|c|c|c|c|c|}
\hline & & 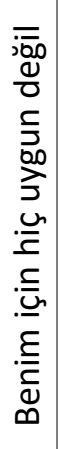 & 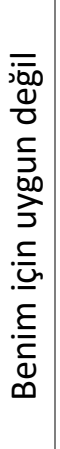 & 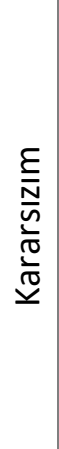 & 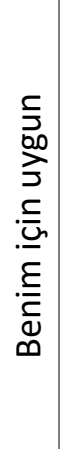 & 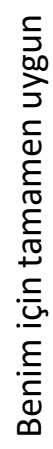 \\
\hline 1 & $\begin{array}{l}\text { Ekran okuma sürecinde okuma amacımdan (oyun, sosyal paylaşım vb. } \\
\text { sitelere girme) uzaklaşırım. }\end{array}$ & 1 & 2 & 3 & 4 & 5 \\
\hline 2 & Ekran okumanın materyalleri depolama kapasitesinden yararlanırım. & 1 & 2 & 3 & 4 & 5 \\
\hline 3 & Ekran okuma sürecinde ana ve alt başlıkları izleyemem. & 1 & 2 & 3 & 4 & 5 \\
\hline 4 & $\begin{array}{l}\text { Bağlantılar (linkler) sayesinde farklı içeriklere ulaşarak metinler arası } \\
\text { anlam kurarım. }\end{array}$ & 1 & 2 & 3 & 4 & 5 \\
\hline 5 & Bilgiye hızlı ulaşmada ekran okumanın gücüne inanırım. & 1 & 2 & 3 & 4 & 5 \\
\hline 6 & $\begin{array}{l}\text { Ekrandaki metnin tamamını okumaktan ziyade vurgulu yerlerini } \\
\text { (kalın, renkli vb. yazılmış) okurum. }\end{array}$ & 1 & 2 & 3 & 4 & 5 \\
\hline 7 & $\begin{array}{l}\text { Ekran okuma sürecinde sayfalarda gezinmek ve istenilen bölüme } \\
\text { atlamak yorucudur. }\end{array}$ & 1 & 2 & 3 & 4 & 5 \\
\hline 8 & $\begin{array}{l}\text { Ekran okuma sürecinde "bul" komutu sayesinde aradığım bilgiler olup } \\
\text { olmadığını değerlendirebilirim. }\end{array}$ & 1 & 2 & 3 & 4 & 5 \\
\hline 9 & $\begin{array}{l}\text { Ekran okuma sürecinde metinleri satır satır okumak yerine atlayarak } \\
\text { okurum. }\end{array}$ & 1 & 2 & 3 & 4 & 5 \\
\hline 10 & $\begin{array}{l}\text { Yoğun bilgi içerisinde okumak istediğim bilgiyi seçmedeki esneklik beni } \\
\text { ekran okumaya teşvik eder. }\end{array}$ & 1 & 2 & 3 & 4 & 5 \\
\hline 11 & $\begin{array}{l}\text { Ekrandaki içeriği görsel, ses, animasyon vb. unsurlarla ilişkilendirerek } \\
\text { anlamlandırırım. }\end{array}$ & 1 & 2 & 3 & 4 & 5 \\
\hline
\end{tabular}




\begin{tabular}{|l|l|l|l|l|l|c|}
\hline 12 & $\begin{array}{l}\text { Ekran okumada metin içi ayrıntıları (ekran ve ekran dışında kalan } \\
\text { içerik) hatırlayabilirim. }\end{array}$ & 1 & 2 & 3 & 4 & 5 \\
\hline 13 & $\begin{array}{l}\text { Okunabilirliği artırmak için ekrandaki ögelerin renk ve boyutlarını } \\
\text { (sayfayı yakınlaştırma-\%, satır aralığı yazı tipi-boyutu-rengi) } \\
\text { ayarlarım. }\end{array}$ & 1 & 2 & 3 & 4 & 5 \\
\hline 14 & $\begin{array}{l}\text { Okuma sürecinde göz-ekran arasındaki mesafeyi uygun şekilde }(30 \mathrm{~cm} \\
\text { kısa olmayacak biçimde) ayarlarım. }\end{array}$ & 1 & 2 & 3 & 4 & 5 \\
\hline 15 & $\begin{array}{l}\text { Ekrana göre basıı metinlerden okurken daha kolay notlar alıım. } \\
16\end{array}$ & 1 & 2 & 3 & 4 & 5 \\
\hline $\begin{array}{l}\text { Okuma sürecinde ekran parlaklığından dolayı ortamın } \\
\text { Işlandırılmasına (ekran parlaklığı ile ortam ışığının uyumlu olması) } \\
\text { dikkat ederim. }\end{array}$ & 1 & 2 & 3 & 4 & 5 \\
\hline
\end{tabular}

Açıklama: Ölçekte toplam 16 madde bulunmaktadır. 1, 2, 7, 8, 11 ve 12. maddeler (6 madde) kullanışııık; 3, 4 ve 5. maddeler ( 3 madde) anlama, 6, 9 ve 10. maddeler ( 3 madde) sayfayı yönetme ve $13,14,15$ ve 16. maddeler (4 madde) göz sağlığı faktörlerine aittir. 